\title{
全天候型分割可搬式インパルス電压発生装置 の開発と接地抵抗非線形特性試験への適用
}

\author{
正員森本痰生（関西電力） \\ 正員林田弘 (関西電力) \\ 正員関烊昇三（関西テック） \\ 非会員 川 正彦 (関西テック) \\ 非会員掼山達哉(ニチコン) \\ 正員森均(ニチコン)
}

Development of Al l-Weather-Type.Mobile Impulse Voltage Ge ne r a t or a nd I t s A p p l i c a t i o n t o Exper ime Non 1 i nearity of Grounding Resistances

Atsuo Morimoto, Member, Hiroshi Hayashida, Member (Kansai Electric Power Co., Inc.), Shozo Sekioka, Member, Masahiko Isokawa, Non-member (Kansai Tech Corporation), Tatsuya Hiyama, Non-member, Hi toshi Mori, Member (Nichicon Corporation)

This paper describes a newly-developed impulse voltage generator (IG). It has the features as follows:

(1) The IG consists of 3 components (a $1.6 \mathrm{HV}$ unit, a $1.4 \mathrm{MV}$ unit and a base box) for the sake of mounting on $10 \mathrm{t}$ trucks, therefore it is easy to move it to a test field.

(2) Capacitors, discharge gaps and a control unit are enclosed in a shelter of fiber reinforced plastics, then it is possible to use the IG in all weathers.

(3) The IG can generate several ten $k A$ when a load is a few ten 2.

(4) Composition of the circuits for lightning/switching impulse voltage/current tests can be easily done by changing the damping and discharge resistance cassettes. Control and data acquisition are made by a personal computer.

As the application of the IG to an outdoor test, the paper presents the characteristics of resistances of a $77 \mathrm{kV}$ substation grounding and a concrete pole when applying a high impulse current. The resistances are dependent on the crest value of the applied current.

キーワード:インパルス電圧発生装置，大電流試験，耐雷設計，接地抵抗

\section{1. 落 言}

電力会社として、需要家に高品質で安定した電力を供給 するという立場から、電力系統において脅威である雷の性 状把暒とその対策等について十分検討することか要求され ている(1) (3)。

最近の各所での活発な雷観测 (4) やEMT P を用いたシ ミュレーション手法の高度化 ${ }^{(5)}$ 、酸化亜銛形避雷器の高
性能化 ${ }^{(6)}$ などの成果により、従来の耐雷設計について見 直をしているところである (7) ( (日)。これら、新しい耐雷 設計について研究や検証を行うためには、より実雷に近い 状態における実験が望まれている。それには、誘雷実験に よる方法 ${ }^{(10)}$ とパルスパワー発生装置を用いる方法 ${ }^{(11)}$ が 考えられる。前者については、冬季雷に多く見られる長波 尾雷などの極めて大きなエネルギーを持った電流に対する 検討を行うことができるが、再現性がなくデータ数につい 
ても多くを期待できないことから種々のパラメータについ て十分な検討を行うことができないという短所がある。一 方、後者については、発生装置が大きなものとなるため固 定して用いられるのが普通である。ところで、電力設備は 鉄塔や発変電所など、屋外に建設されていることが多いと とむに規模が大きくそれらが有機的に結びついている。そ のため、電力設備を対象とした実験は現地で行うことが要 求される。筆者らは、現地で限られた時間内に種々のパラ メータの影響について検討する必要があることから、パル スパワー発生装置を用いる方法を啋用した。また、装置と しての実綪および取り扱いやすさの点から、コンデンサ型 のインパルス電圧発生装置が適しているものと考えた。

本論文では以上の観点から、新たに開発した、容易に橾 隔地に移設可能であり、天候の影㸷を受けず、また、数 10

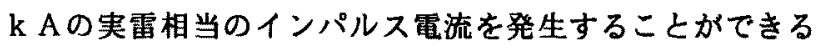
全天候型分割可搬式インパルス電圧発生装置の概要につい て述へる。さらに、本装置を用いた実験例として、変電所 接地網および配電用コンクリート柱のインパルス大電流特 性について述べ。

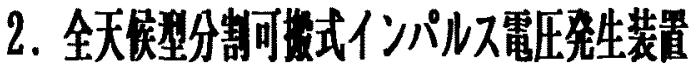

〈2.1〉開発目的と閥発㵊題新たに開発したインパ ルス電圧発生装置（以下新 $\mathrm{I} \mathrm{G}$ 称する）は、500kV変電 所など実設備について試験・検証を行うことができること および実雷相当の実験を行うことができることを目的とし ている。このことから、新 I Gの仕様として以下のものを 想定した。

表 1 新 I Gの目的亡要求仕様

Táble 1. Demands and specifications of newly-developed IG.

\begin{tabular}{|c|c|}
\hline 的 & 要 求 仕 様 \\
\hline $\begin{array}{l}\text { (1)装電所など、実設備での } \\
\text { 試験・榆証ができる。 }\end{array}$ & $\begin{array}{l}\text { 分割可搬型とし機動性をも } \\
\text { たす。 }\end{array}$ \\
\hline 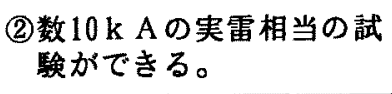 & $\begin{array}{l}\text { 総電荷量が大きく内部イン } \\
\text { ピーダンスがさい。 }\end{array}$ \\
\hline $\begin{array}{l}\text { (3)天候に左右されず試験が } \\
\text { できる。 }\end{array}$ & $\begin{array}{r}\text { 耐候性で防湿防水形とする。 } \\
\text { (全天候型) }\end{array}$ \\
\hline $\begin{array}{l}\text { (4) } 500 \mathrm{kV} \text { 機器の耐電圧試 } \\
\text { 娩ができる。 }\end{array}$ & $\begin{array}{l}\text { 充電電王が大きく回路変更 } \\
\text { が容易なものとする。 }\end{array}$ \\
\hline $\begin{array}{l}\text { (5)制御・計測が容易にでき } \\
\text { る。 }\end{array}$ & $\begin{array}{l}\text { 人間が操作・判断する部分 } \\
\text { が少ない。 }\end{array}$ \\
\hline
\end{tabular}

〈2.2〉新 I Gの仕样遥定理由と䃌要 新 I G は、1 ンパルス電圧発生装置としての機能の他に大電流を発生す る、すなわちインパルス電流発生装置（ＩＣＧ）の機能も 備え持つ。

表 1 に示す要求仕椂に従い開発した本装置の仕様に関す る選定理由と概要を以下に述べ。
(1)分割可投型 新 I G は、目的(1)上り実祭の電力設備 について試験および検証を行うことを目的としている。電 力設備は山間部などに建設されていることが多いことから トラックに搭載して現地に輸送する必要がある。また、充 電電圧は目的(4)より数 MV 必要であるから、新 I Gの高さ は $10 \mathrm{~m}$ 以上となるため袮数のユニットに分割して輸送しな ければならない。従って、新 I G は横倒しによるトラック 輸送に耐える機械的強度を有するとともに分割および再組 立作業が安全かつ容易に実施できる構造とした。また、分 割した各ユニットの寸法は、公道を許可無く走行できる軽 車両の保安基準（高さ $3.8 \mathrm{~m}$ 以内、愊 $2.5 \mathrm{~m}$ 以内）を满たす ように選定した。新 I G 本体以外に、開閒インパルス用波 頭調整器を兼ねたC R 分圧器も分割可搬型とし、新 I Gの 制御および計測を行う制御室もそれぞれトラック輸送可能 とした。

最大充電電圧は、 $500 \mathrm{k} \mathrm{V}$ 送電線におけるアークホーン の標準雷インパルスに対する50\%フラッシオーバ電圧が約 2. $2 \mathrm{MV}$ (12) であることから、これに利用率や裕度などを 考虑して $3 \mathrm{MV}$ とした。この值は $500 \mathrm{k} \mathrm{V}$ 発変電機器の試 酸電压 $1.8 \mathrm{MV}^{(18)}$ に対しても十分な值である。

重量物を運搬する際に、一般に $4 \mathrm{t}$ トラックまたは $10 \mathrm{t}$ トラックが用いられている。4 tトラックを用いる方が大 型運転免許を必要とせず、また小回りが利くため輸送手段 として望ましい。しかしながら最大充電電仕を $3 \mathrm{MV}$ とし たとき、表 2 に示す通り総重量は $21.8 \mathrm{t}$ となる。従って 4 tトラックを用いた場合には分割数が 6 となり、10 t トラ ックを用いた場合の分割数 3 に比べ分割数が 2 倍となるこ とにより、分解や組立などにおける作業効率が著しく低下 するとともに接繶箇所が增えることによる故障発生頻度の 增大を招く恐饥がある。従って、新 I Gの輸送には10 t ラックを用いることとし、本体は、1.4M Vュニット、1.6 M V ユニットおよび充電器や始動ギャップなどからなる台 箱の 3 つに分割した。また、将来ユニット追加により增容 量可能な構造とした。

図 1 に関西電力総合技術研究所高電圧実験室における設 置状況を示す。また、図 2 に総合技術研究所から関西電力 山椅実験センターへ運搬および据付を行った際の状況を示 す。なお、この際の運搬および据付はそれぞれ 7 時間程度 で完了した。

(2)小型軽量で大容量の単位コンデンサ 目的(2)におい て発生電流波高值が大きいほど、より電圧階級の高い系統 について検討を行うことができる。しかしながら、超高压 系統を対象とした場合、想定雷撃電流は $100 \mathrm{k} \mathrm{A}$ 以上とな り極めて大きな装置が必要となる。よって、装置開発にお

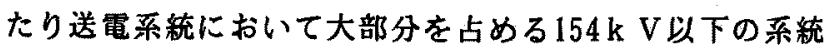
における想定雷撃電流 $60 \mathrm{k} \mathrm{A}^{(3)}$ を目標值とした。

インパルス大電流を発生させるためには、充電電圧が大 きいとともに、回路のインダクタンスが小さく静電容量が 大きい必要がある（付録参照）。しかしながら充電電圧を 大きくしようとすれば、多数のコンデンサを直列に接続す 


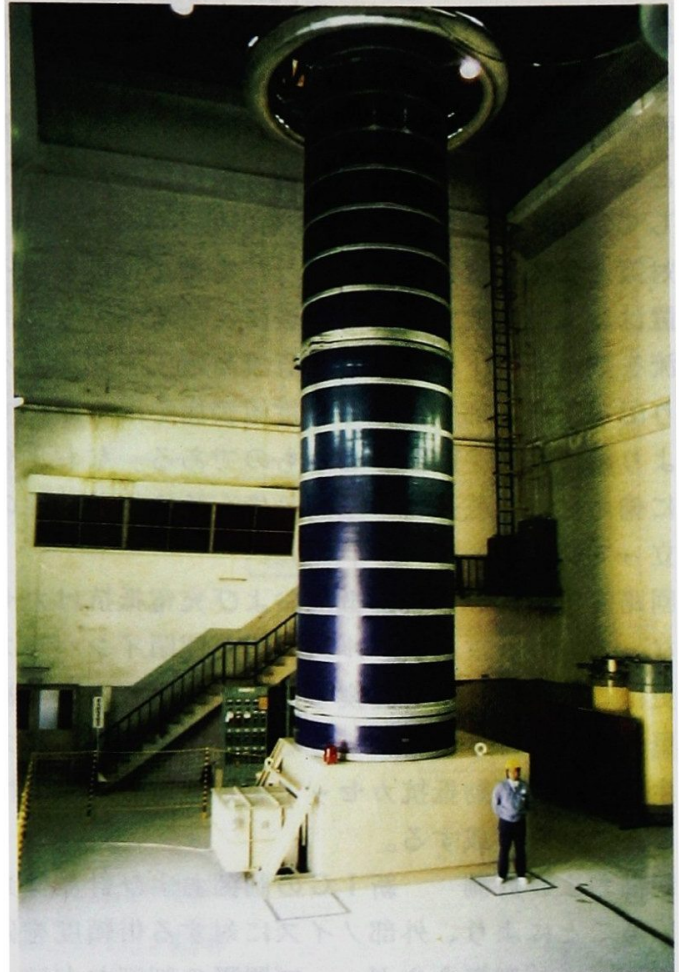

図 1 全天候型可搬式インパルス電圧発生装置 Fig. 1. All-weather-type mobile impulse vol tage generator.

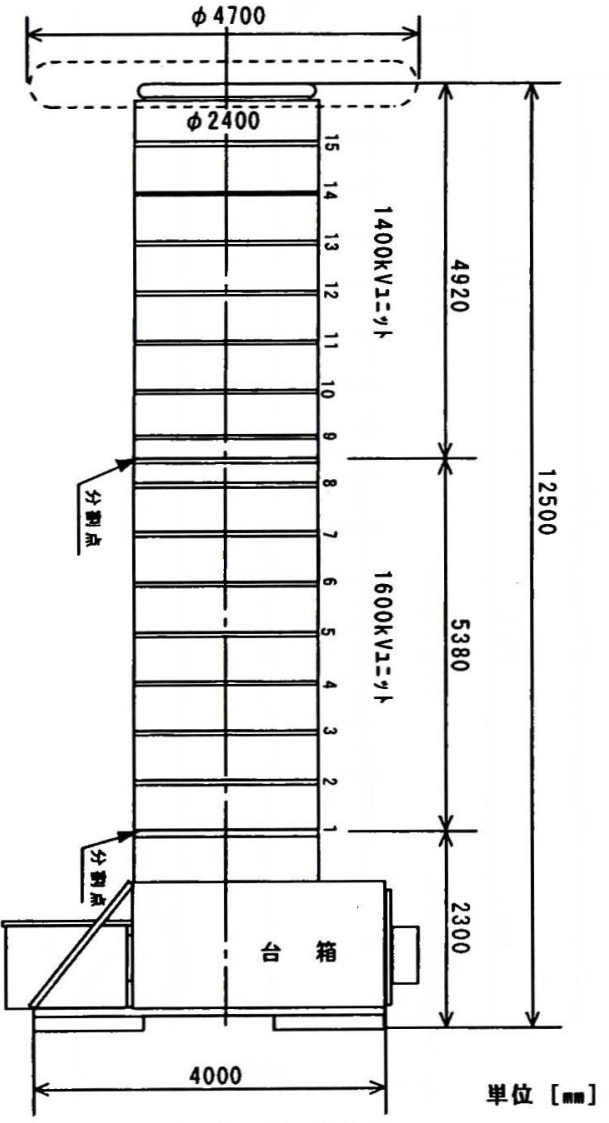

(a) 側面図

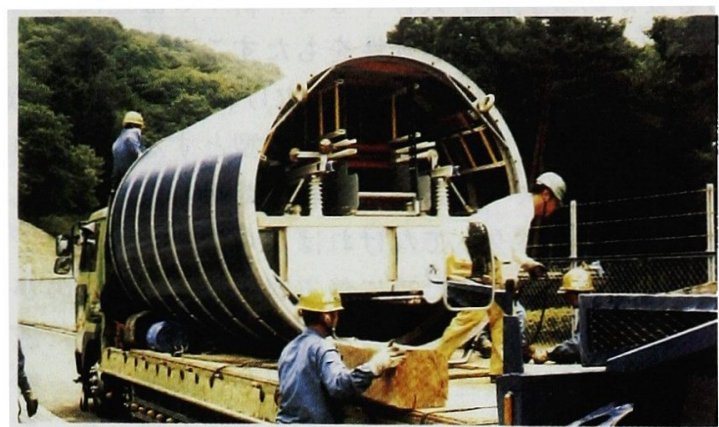

（a）搬入

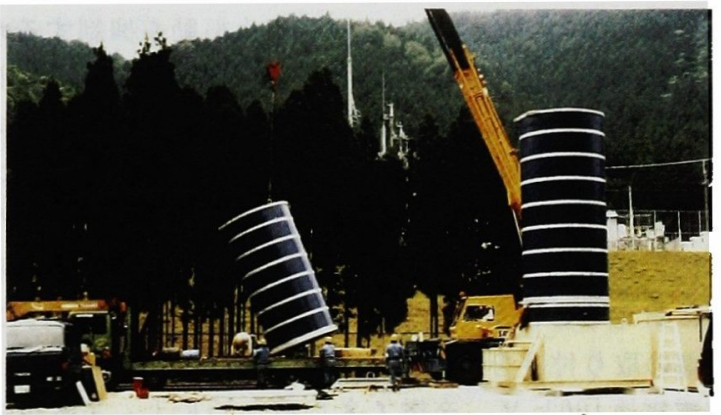

(b) 組み立て

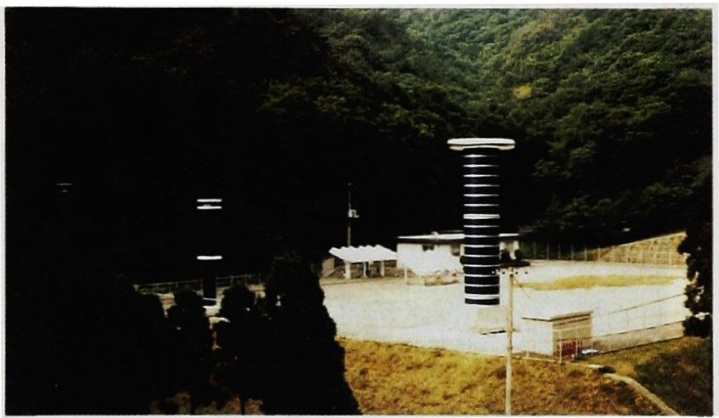

（c）据え付け完了

図 2 総合技術研究所から山崎実験センターへ の新 I G 移設状況

Fig. 2. Transportation of newly-developed IG from Technical Research Center and installation at Yamasaki Test Center.

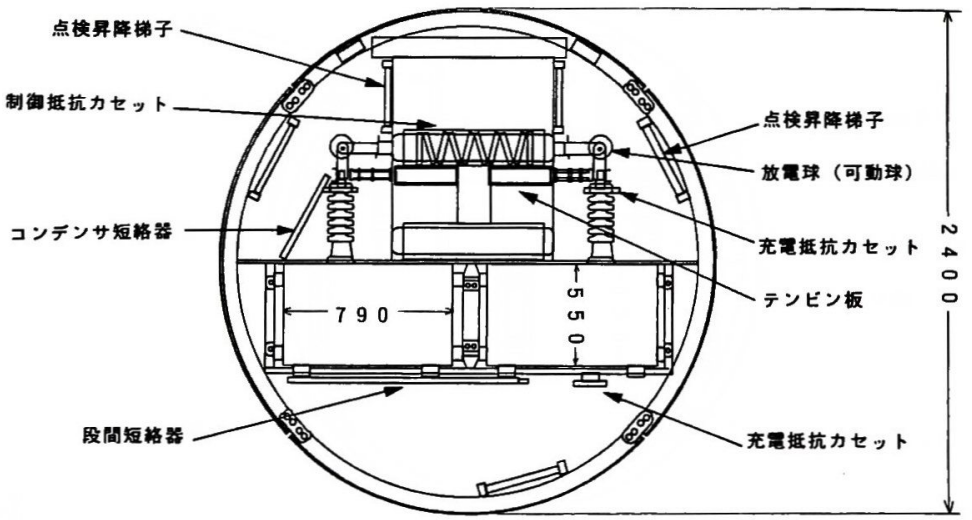

(b) 断面図

図 3 新 I G 構造図

Fig. 3. Construction of newly-developed IG. 
る必要があり装置が大きくなる。新 I G は先に述べたよう に分割可搬式により機動性をもたすことを目的としている ためできるだけ容積を小さくしなければならない。従って、 単位コンデンの大きさは、可搬型とするための物理的な 制限内で作業スペースおよび絶縁距離を確保するためにで きるだけコンパクトでなければならない。同時に I C G と しての機能を持たすために静電容量は大きいものが必要で ある。このため、絶縁油およびコンデンサ薄紙に誘電率が 高く絶縁耐力の大きなものを使用し、エネルギー密度を従 来品の $15 \%$ 增とすることにより小型化を図った。また、I $\mathrm{G}$ 内部回路の残留インダクタンスの低減については、I G 動作時において段間に発生する寄生振動を抑制するために 必要な制動抵抗器として折り返し金属䈃抵抗を内蔵したコ ンテンサを用いることにより、インダクタンス成分の主た

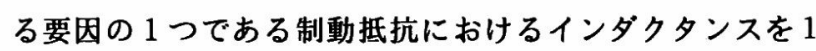
個当たり $3 \mathrm{n} \mathrm{H}$ (従来品の約 $1 / 10$ ) に低減 (14)した。さ らに、60k Aのインパルス大電流が流れた際に生じる電磁 力に耐えることができるように、コンテンサブッシングや 各部の取り付けを強固にした。以上により静電容量 $3 \mu \mathrm{F}$ 、

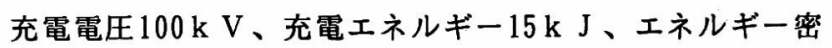
度 $0.11 \mathrm{k} \mathrm{J} / \ell$ の単位コンデンサを開発した。

図 3 に新 I Gの侧面図および断面図を示す。また、図 4 に60k Aのインパルス大電流を発生させた際の測定結果を 示す。

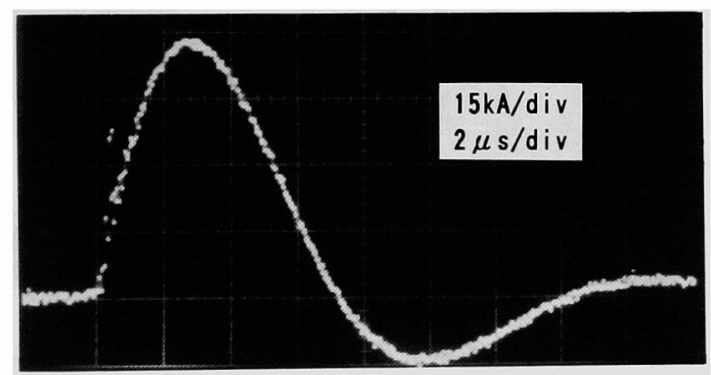

（a）正極性

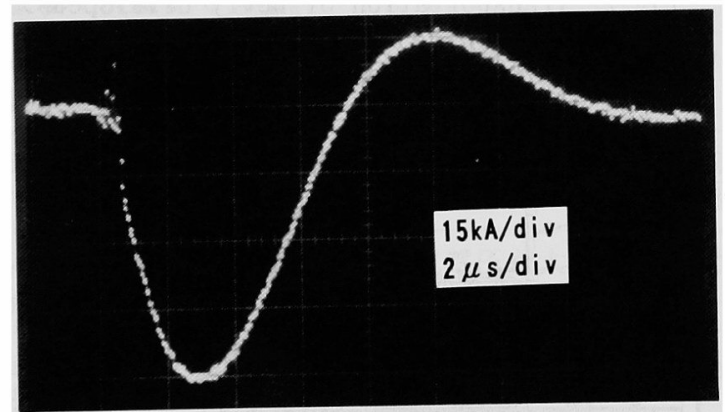

(b) 負極性

図 4 インパルス大電流測定結果 $\left(\mathrm{I}_{\text {max }}=60 \mathrm{k} \mathrm{A}\right.$ )

Fig. 4. Measured results of high impulse current $\left(I_{\max }=60 \mathrm{kA}\right)$.

(3)全天候型 充電部を $16 \mathrm{~m} \mathrm{~m}$ 厚の F R P 製外壁で密閉 するとともに内部に乾燥器および空調設備を備え付けた。 これにより、雨天時などにおいても安定した始動放電が可 能であり、悪天候によって実験を中断あるいは中止するこ
となく行うことができる。

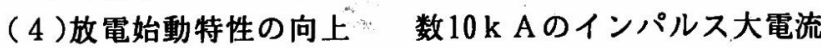
を発生させた際に放電ギャップ（銅タングステン合金製） の表面金属がアークにより蒸発し、周囲の空気・炭酸ガス などと結合してできた金属酸化物と金属粉が電極の表面に 付着して放電ギャップ間の耐電圧が低下することがある。 この対策として、放電洗浄装置 (15) を備え付けている。こ の装置は、大電流放電を行った後に、放電ギャップ間に短 絡電流を数 $\mathrm{m}$ A以下に制限した直流高電圧を印加すること により耐電圧低下部で放電させ電極表面を滑らかにするこ とにより絶縁耐力を回復させるむのである。なお I G 本体 内部に備え付けた乾燥器・空調設備も放電始動特性の向上 に役立っている。

（5）回路変更方式制動抵抗および充電抵抗はカセッ卜 式となっており、雷インパルス回路と開閉インパルス回路 の変更はこのカセットを交換することにより行うため、回 路変更を容易に行うことができる。また、インパルス大電 流発生回路は、制動抵抗力セットを短絡用カセットに交換 することにより作成する。

（6 制御および計測 新 I G の制御および計測は光伝送 を用いることにより、外部ノイズに対する信頼度を確保し た。また、充放電指令やギャップ間隔の制御などはパーソ ナルコンピューターによる対話型として操作を容易に行う ことができる。運転モードは、単発運転と自動運転（自動 繰り返し、自動昇圧、50\%フラッシオーバ電圧測定）のモ 一ドを用意し、機器などの耐圧試験が容易に実施できるよ うにした。自動繰り返し試験時における表示画面例を図 5 に示す。

IG-3000 REPEATING OPERATION

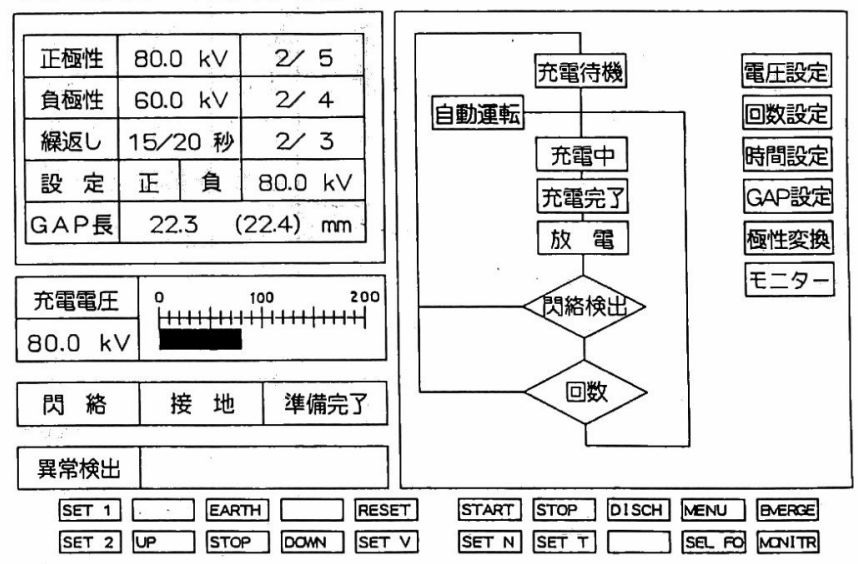

図 5 表示画面例 (自動繰り返し試験)

Fig. 5. Example of sketch of CRT in controlling newly-developed IG (automatic repeating test).

測定結果は、テジタイザーに取り込んだデータをC R T 画面に表示すると共に、プロッタやティスク装置へ記録す ることができる。制御および測定系に関するブロック図を 図 6 に示す。 


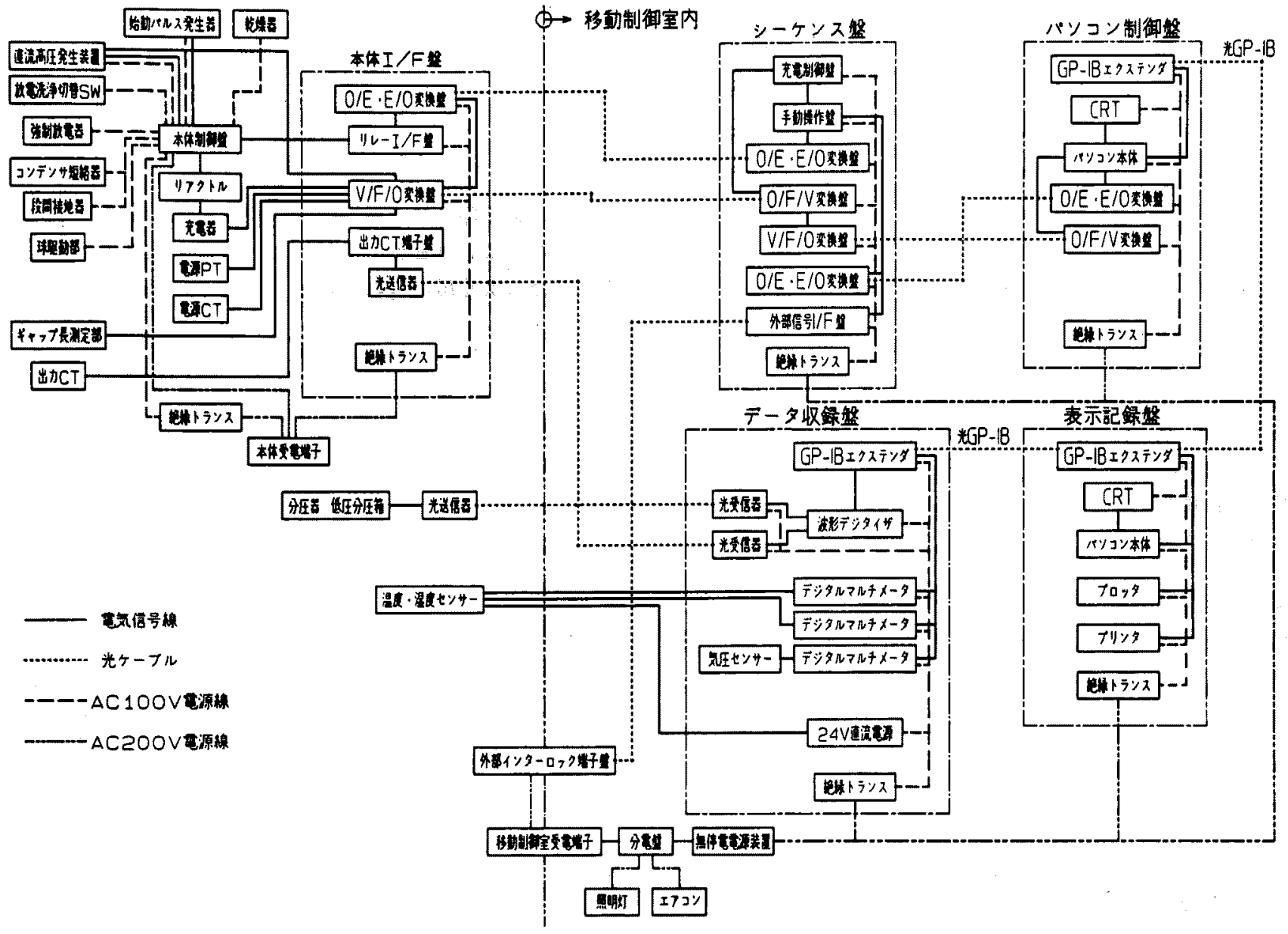

図 6 制御・計測系ブロック図

Fig. 6. Block diagram of control and measurement system.

以上より、新 I Gの仕様のまとめを表 2 に示す。

表 2 新 I Gの仕様

Table 2. Specfications of newly-developed IG.

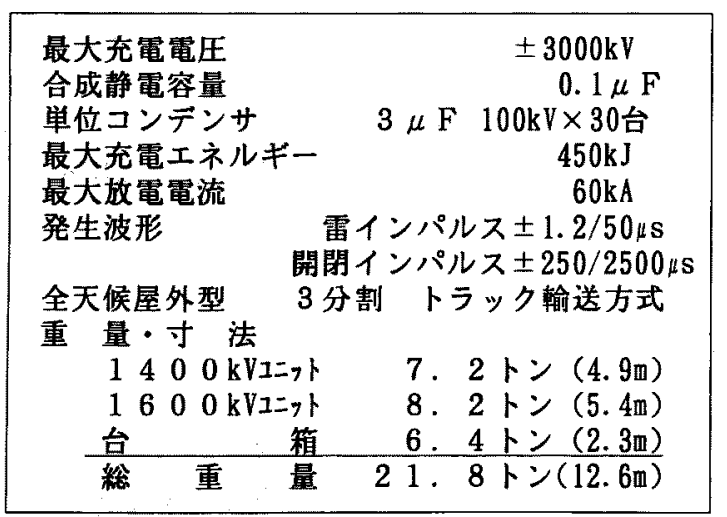

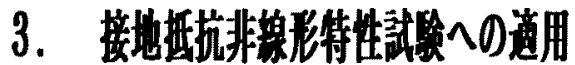

本章では、新 I Gの特街であるインパルス大電流を発生 させた試験の例として、77 k V 系怒電所を模提した接地網 (16) (17)ならびに配電用コンクリート柱 ${ }^{(18)}$ における接地
抵抗非線形特性試験のあらましについて述へる。一般に急 浚波電流に対して接地抵抗は過渡特性を持っているため接 地インピーダンスと表現すべきであるが、通常、接地抵抗 と表現されているため、本稿でも接地抵抗と呼ふことにす る。

これらの実験を行った山䢛実験センターにおける実験配 置図を図 7 に示す。

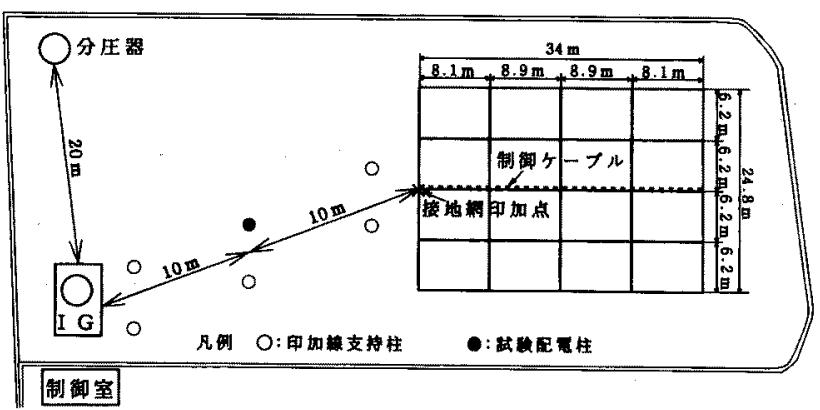

図 7 実験場配置図

Fig. 7. Experimental arrangement.

本実験における新 I Gの接地は、長さ $1.5 \mathrm{~m}$ の接地棒を 
$1.5 \times 1.5 \mathrm{~m}$ 間隔で70本打ち込みそれらを連結したものを使 用した（定常抵抗 $4 \Omega$ )。なお、実験場所での大地固有抵

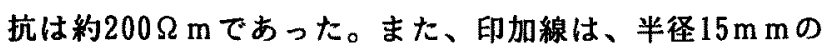
アルミパイプ 8 本を半径 $250 \mathrm{~m} \mathrm{~m}$ のリング上に配置した複 導体を使用することによりインダクタンスを低减するとと むにコロナの発生を防止している。

〈3. 1〉変電所接地㮶 $77 \mathrm{k} \mathrm{V}$ 系変電所における接地 網を想定し、接地網のインパルス大電流特性および接地網 上に布設した制御ケーブルに発生する電圧を測定した。

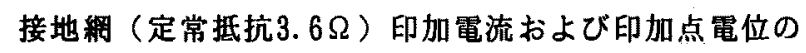
測定波形例を図 8 に示す。ただし、電位測定はノイズをで きるだけ小さくするため実験場所から約 $200 \mathrm{~m}$ 橾方の接地 点から印加線と平面上で直交するように地表面に沿わした (18) 電圧補助線 ( I V $2 \mathrm{~m} \mathrm{~m}^{2}$ ) を抵抗分压器を介して印 加点と接続して行った。

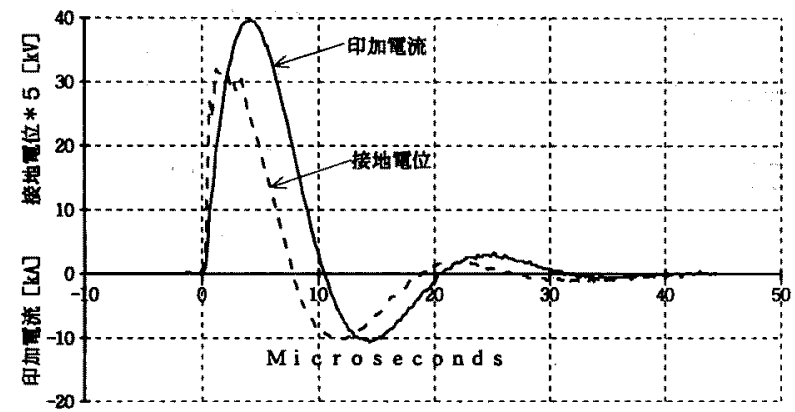

図 8 接地網大電流特性試験測定例

Fig. 8. Example of high current characteristics of mesh type grounding.

接地抵抗は過渡特性を持っているため、図 8 から明らか なように、電圧と電流の間には位相のずれがある。本稿で は简単のため、(1)式で定義したインピーダンスを用いて、 印加電流波高值が接地抵抗に与える影整について述べる。

$$
Z=\frac{\text { 印加点電位波高值 }}{\text { 印加電流波高值 }}
$$

(1)式による接地網接地抵抗の電流波高值依存特性を図 9 に示す。これより、印加電流波高值が大きくなると抵抗 が低下していくのがわかる。また、極性による差異は見受 けられない。

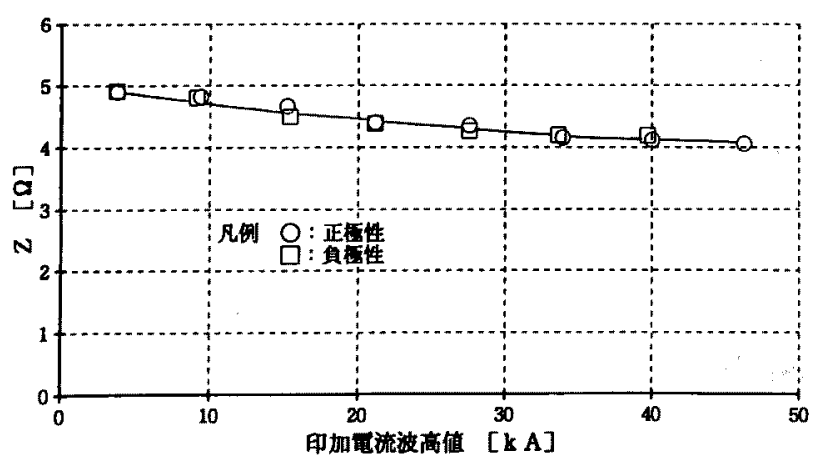

図 9 接地網接地抵抗電流波高值依存特性

Fig. 9. Impedance characteristic of mesh type grounding as a function of the crest current.

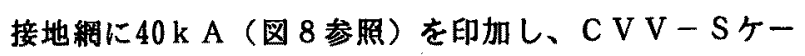
ブルの終端において心線と金属シース間にッェナーダイオ ード (制限電圧10V) を挿入したときに、ツェナーダイオ 一ドの端子間に発生した電圧を図10に示す。ただし、制御 ケーブルの金属シースは、印加点侧では接地網に接続し終 端は開放した。また、心線は両端を開放した。図10より、 2 回目の電流印加時にツェナーダイオードが絶縁破壊した ことがわかる。ツェナーダイオードは低圧制御回路を保護 するためによく用いられており(20)、また、低圧制御回路 障害の実態調查結果においてダイオードに関する障害が多 数を占めている(21)。今回、接地網電流の誘導によりダイ オードを絶縁破壊できたことにより、低圧制御回路障害に 関する実規模相当の検討を行うことができる。

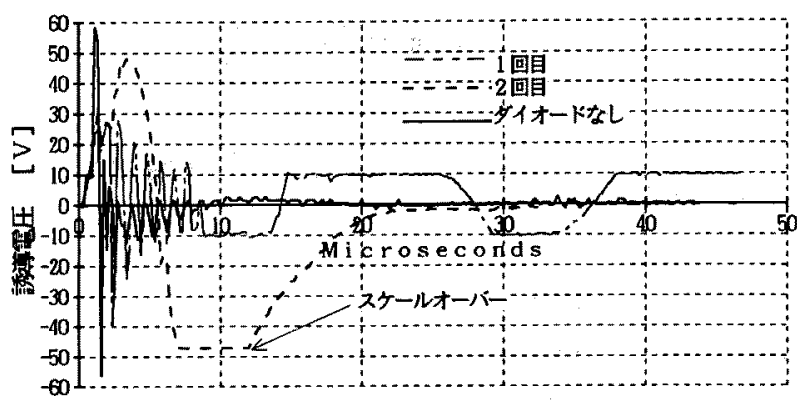

図 10 制御ケーブル誘導電圧

Fig. 10. Induced voltages on control cable.

〈3. 2〉コンクリート柱コンクリート柱の塔頂にお いて、むき出しにした鉄筋に電流を印加したときの印加電 流および塔頂電圧の測定例を図11に、(1)式によるコンク リート柱の電流波高值依存特性を図12に示す。コンクリー

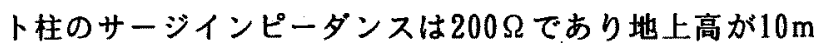
であること (18) から、インダクタンスは20/3 $\mu \mathrm{H}$ となる。 従って、波頭長が数 $\mu$ sである印加電流に対してコンクリ 一ト柱のインダクタンスが塔頂電圧に与える影帮は数 $\Omega$ 程 度となり、接地抵抗 $40 \Omega{ }^{(18)}$ に対してかなり小さいため、 電圧の大部分は接地抵抗による電圧降下であると考えるこ とができる。なお、塔頂電压の測定は C R 分圧器を用いて 行い、新I Gの回路として雷インパルス回路と大電流イン パルス回路を用いた。

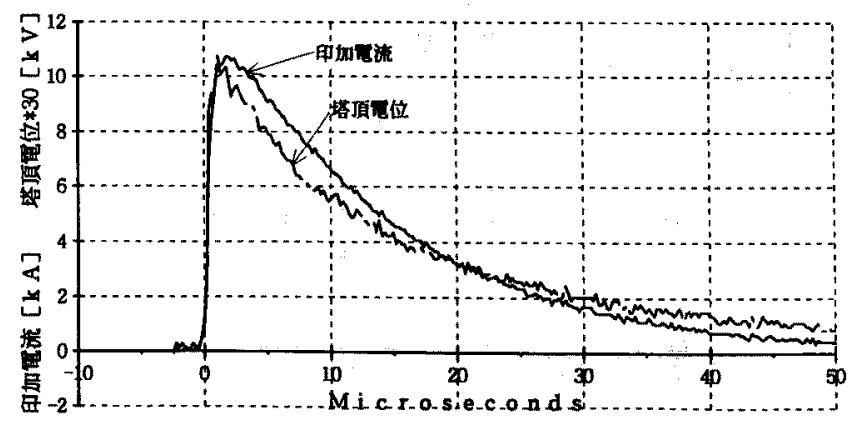

図11コンクリート柱大電流特性試験测定例 Fig. 11. Example of high current characteristics of concrete pole. 


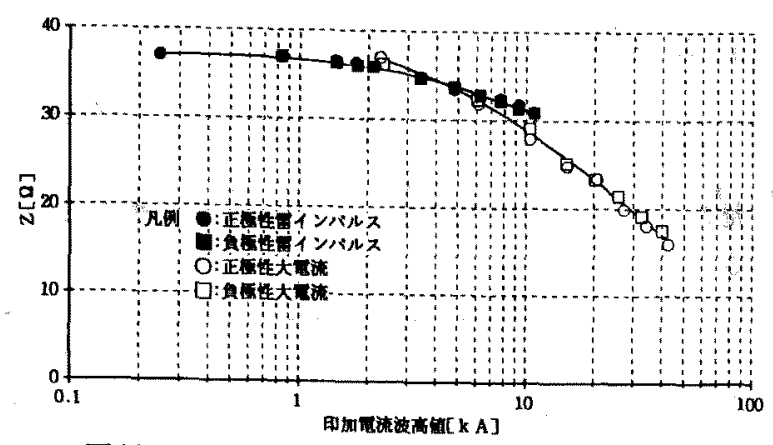

図12 コンクリート柱の電流波高值体存特性

Fig. 12. Impedance characteristic of concrete pole as a function of the crest current.

図 9 と図12を比較すると、接地網に比べコンクリート柱 の方が電流波离值依存性が大きいことがわかる。これら、 印加電流が大きくなるにつれ接地抵抗が低下するのは、土 中放電によるおの ${ }^{(22)}$ と考えられる。

以上、新 I Gを用いた大電流試験の例を示したが、短波

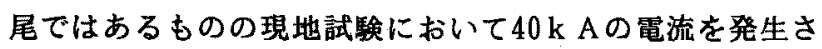
せることができた。このときには、能力の $60 \%$ 程度であっ た。また、コンクリート柱における試験では標準雷インパ

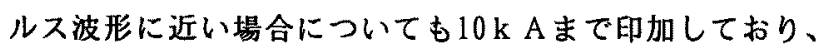
従来検討できなかった雷笔流領域における現地実験を容易 に行うことができるものと考えられる。

\section{4. 耤言}

本稿では、新たに開発した全天候型分割可搬式インパル ス電王発生装置の概要とその適用例について述へた。本装 置は、遠隔地に運搬可能であり、天候の影響を受けないこ とから、変電所などの現地試験に適しているとともに数 10 k Aのインパルス大電流が発生できる特街を有している。 今後は、新設の変電所や送電線などにおけるフィールド試 験、環境の変化が絶縁特性に与える影㗽等について本装置 を適用していきたいと考える。

最後に、本装置を開発するに当たり、関西電力関係各位、 関西テック杉本览理事ならびにニチコン田実顧問に は衔援助ならびに責重な御意見を睗りました。また、電力 中央研究所三宅久仁彦塩原実験場々長には全般に渡り貫 重な御意見を睗りました。これらの方々に謝意を表します。 (平成 7 年 1 月 5 日受付、同年 5 月 1 日再受付)

\section{参考文触}

(1)電中研耐雷設計委員会送電線分科会：「送電線耐雷設 計ガイドブック」，電中研報告 175031 (1976)

(2)電中研耐雷設計委員会配電線分科会：「配電線耐雷設 計ガイドブック」，同上 175030 (1976)

(3)電中研耐雷設計委員会発変電分科会：「発変電耐雷設 計ガイドブック」，同上 175034 (1976)

(4)雷観測調查専門委員会：「最近の雷観測技術と今後の 課題」，電気学会技埌 第487号（1994）
(5)雨谷：「過渡現象解析ブログラムE M T P の最近の動 向」，電学誌 vol.113(11)，pp. 936-944 (1993)

(6)酸化垔鉊形避雷器の特性評価試験法調査專門委員会: 「酸化西銛形避雷器の特性亡評価試験法」，電気学会 技報第474号 (1993)

(7)酸化亜鉛素子の線路保護への適用調查専門委員会 : 「送電用避雷装置の開発状況と適用効果」，同上第 367 号 (1991)

( 8 )横山: 「架空配電線の直撃雷対策」, 電学論 B vol. $114(6)$, pp. 564-568 (1994)

(9)絶縁設計合理化専門委貝会:「絶縁設計の合理化」, 電気協同研究 第 44 巻 3 号 (昭63)

(10)樓野・整庭・石橋・堀井：「冬季ロケット誘雷に伴う 配電線誘導電圧ならびに架空地線による抑制効果の測 定」, 電学論 B vol. 105(4), pp. 331-338 (1985)

(11)原・秋山：高電圧パルスパワー工学 (1991) 森北出 版

(12)河野：系統絶縁論 （1984）コロナ社

(13)「試験電圧標準」、JEC-193 (1974)

（14）田・寺村：「低インダクタンス C R 複合部品」，特許, No. 1748018

（15）田・桶山：「㣫擊電圧・電流発生装置」，特許公開No. 昭64-26370

(16)森本・林田・関岡・福園・長岡・雨谷：「77k V変電 所接地網インピーダンスのインパルス大電流特性」, 平成 7 年度電気学会全国大会 1608

(17)関岡 - 福園 - 森本 - 林田 - 長岡・雨谷：「接地網電流 による制御ケーブル誘導電圧の測定」, 平成 7 年度䉓 気学会全国大会 1609

(18)関岡・山本・横山：「コンクリート柱のインパルス大 電流特性に関する実験的検討」, 高電压研究会 HV-94 -176 (1994)

(19)郷津 - 森田・東狐・神山・井上：「接地抵抗過渡特性 测定法に関する実証試験結果」, 放電・高電圧研究会 ED-91-150, HV-91-67 (1991)

(20)低圧制御回路絶縁設計専門委員会：「低圧制御回路絶 縁設計」，電気協同研究 第 32 巻 2 号（昭51）

(21)長谷川・東狐・金森・伊井・閣岡：「発変電所におけ る低圧制御回路の雷害実態调查結果の分析」，平成 2 年度電気学会全国大会, 1218

(22)A. M. Mousa: "The Soil Ionization Gradient Associated with Discharge of High Currents into Concentrated Electrodes", IEEE Trans., vol. PNRD-9(3) pp. 1669-1677 (1994)

(23)鶴見・河野 - 山本・河村：高電圧工学 （1981）電気 学会

讨 録

インパルス大電流の式 
インパルス電流発生回路がR L C の直列回路で表され るとき、電流波高值 $\mathrm{i} \mathrm{max}$ は(付 1 ) 式で表される (2s)。

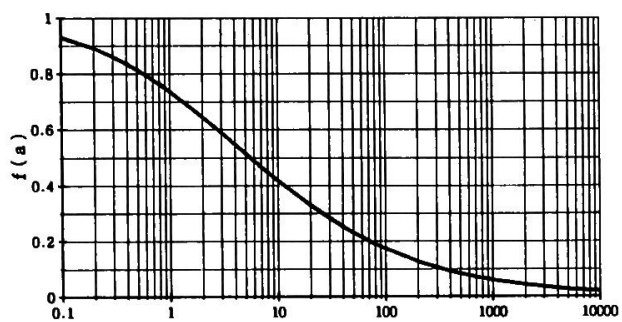

付図 1 インパルス電流波形係数

App.fig. 1. Coefficient of impulse current.

森本 淳生（正員）1947年11月14日生。66年 3 月関 電学園卒業。同年 4 月関西電力踭入社。 同社総合技術研究所にて雷害および鳥害 に関する研究に従事。現在，中央送変電 建設事務所変電工事係長。

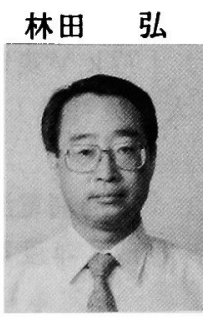

（正員）1946年 4 月29日生。70年 3 月同 志社大学工学部電気工学科卒業。同年 4 月関西電力㑣入社。現在，同社総合技術 研究所発電設備研究室(水力変電)主幹。 主として, 水力変電設備に関する研究に 従事。

煳岡 升三（正員）1963年12月30日生。86年 3 月同 志社大学工学部電気工学科卒業。87年 7 月踭関西テック入社。主として，電力系 統における雷サージ解析に関する研究に 従事。日本大気電気学会会員。

$$
\left.\begin{array}{rl}
i_{\max } & =\frac{E}{R} f(a) \\
a & =\frac{4 L}{C R^{2}}
\end{array}\right\}
$$

ただし、 $\mathrm{E}$ ：充電々圧、f（a）：付図 1 で表され る $\mathrm{a}$ の関数

（付 1 )式より、電流波高值は充電電圧に比例する。また 付図 1 より、a が小さい程、すなわち C が大きく L が小さ いほど電流波高值が大きくなることが分かる。従って、大 電流を得るためには、総電荷量（＝Ｃ E）を大きくし内部 インダクタンスをできるだけ小さくする必要がある。

磯川 正彦 （非会貝）1959年9月7日生。78年 3 月大

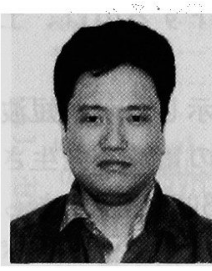
阪府立布施工業高等学校電気科卒業。同 年 4 月関西テック入社。主として, 高 電圧，雷サージに関する研究に従事。現 在, 同社技術応用部副長。

桶山達哉（非会員）1944年 6 月26日生。68年 3 月

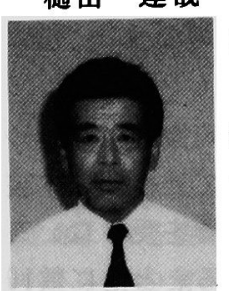
同志社大学工学部電気工学科卒業。同年 4 月日本コンデンサエ業㑣)（現ニチコン (社。主に直流高電圧・インパルス 電圧発生装置の開発・設計に従事。現在, 同社草津工場特機部特機技術一課長。

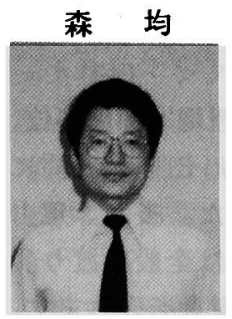

（正員）1958年 3 月 2 日生。 80 年 3 月東 京工業大学工学部電気・電子工学科卒業。 82 年 3 月同大学大学院理工学研究科修士 課程（電気・電子工学専攻）修了。同年 4 月日本コンテンサ工業(侏) (現ニチコン (揦) 入社。主に高電圧・パルス大電流発 生装置の開発・設計に従事。現在同社草 津工場特機部特機技術一課技師。 